This is an author generated post-print of the article:

Russo, M., Gama, C., Monteiro, A. How does upgrading an emissions inventory affect air quality simulations? Air Quality, Atmosphere and Health 12, 731-741, June 2019.

The final publication is available at http://dx.doi.org/10.1007/s11869-019-00692-x 


\title{
HOW DOES UPGRADING AN EMISSIONS INVENTORY AFFECT AIR QUALITY SIMULATIONS?
}

\author{
M. A. Russo ${ }^{1 *}$, C. Gama ${ }^{1}$, A. Monteiro ${ }^{1}$ \\ ${ }^{1}$ CESAM \& Department of Environment and Planning, University of Aveiro, Aveiro, Portugal \\ *Corresponding author: M.A. Russo, e-mail: michaelarusso@ua.pt
}

\begin{abstract}
Each year all Member States (MS) have to deliver their national emissions inventory to the European Union for all activity sectors, following the requirements of the CLRTAP programme. Recently the specifications of this emissions report changed, MS emissions data had to be reported in grid cells with a resolution of $0.5^{\circ} \times 0.5^{\circ}$, and now, from 2015 forward, they must use a higher resolution grid $\left(0.1^{\circ} \times 0.1^{\circ}\right)$. The purpose of this study is to investigate the main differences found between these two emissions inventories for Europe, focusing on Portugal as a case study, using their available common year (2015). Differences on emission values and their spatial distribution were analysed per sector and pollutant. Additionally, to evaluate and compare the accuracy of both datasets, air quality modelling simulations were performed, and the resulting pollutant concentrations were validated using data from observations. The results found indicated major differences in several MS (e.g. France, Italy, Germany and Spain). Portugal was not one of the delta hotspot but significant differences were still found, mainly for NOx emissions for the transport sectors, both emissions and concentrations in urban areas, as well as $\mathrm{NO}_{2}$ concentrations throughout the study domain. The analysis of the air quality modelling outputs indicates that the EMEP0.1 inventory does not improve model performance, which suggest that the methodology to build EMEP0.1 was not adequate. This work highlights the importance of accurately estimating emission data and confirms what other studies already indicated regarding uncertainties; solely improving the emissions inventory resolution does not necessarily imply higher accuracy in the results.
\end{abstract}

Keywords: atmospheric emissions; EMEP inventory; inventory resolution; air quality modelling; Portugal

\section{INTRODUCTION}

Emission data is an important part of air quality modelling and plays a central role in the accuracy and credibility of modelling results. Incomplete datasets or inaccurate estimates can significantly impair our ability to evaluate the impact of emission sources on air quality, or perform a detailed 
analysis of emission scenarios (Davidson and Kanter 2014; Quilcaille et al. 2018). There will always be a need to output reliable, accurate and up-to-date emissions inventories for air quality studies. In addition, knowing the uncertainty in emissions and measured air quality data is key to understand the level of confidence in the results, and has been widely discussed in the scientific community (Lindley et al. 2000; Winiwarter and Rypdal 2001; Zheng et al. 2009, 2017; Milne et al. 2014; La Notte et al. 2018; Pisoni et al. 2018). By minimizing uncertainty we can have reliable sources of data, which will in turn allow for a more consistent and accurate input for policy makers to make the best decisions. The EMEP Centre on Emission Inventories and Projections (CEIP, ceip.at) is tasked with collecting data related to the Convention on Long-range Transboundary Air Pollution (CLRTAP), which requires qualified scientific information focusing on three main activities: collection of emission data, atmospheric and precipitation measurements and air quality modelling. Since various assumptions have to be made, there are numerous sources of uncertainty when estimating data using emission models, including activity data of the polluting activity or incorrect emission factors from polluting sources (Briggs 1995; Pacyna and Graedel 1995; Zachariadis and Samaras 1997). For spatially resolved inventories, there is an additional layer of uncertainty due to the need of including the spatial distribution of the emissions. The task of calculating uncertainties when faced with a large number of different methods, estimates and models can be very complex (Pacyna and Graedel 1995; Mobely and Saeger 1996), as such, having any type of data associated with uncertainties is a valuable asset.

Currently, the most widely used emissions inventory is EMEP, which has recently updated its horizontal resolution, from $0.5^{\circ} \times 0.5^{\circ}$ to $0.1^{\circ} \times 0.1^{\circ}$. This study aims to assess the main differences in both the emission inventory data that are used as input to an air quality model (spatial distribution and emission values) as well as air quality modelling results, to evaluate the accuracy of each inventory. Since 2015 is the common and updated year between the inventories, simulations were made for a summer and winter month, June and December 2016, using these emissions.

There are other emissions inventories with data available for Europe, such as EDGAR, EPRTR and TNO. These are independent from the EMEP database and can have sources of data, namely, a global dataset (EDGAR, http://edgar.jrc.ec.europa.eu/overview.php), a database of European Pollutant Release and Transfer Register (EPRTR, http://prtr.ec.europa.eu) or officially reported data together with model and expert estimates (TNO, Kuenen et al., 2014).

In Europe, each country is responsible for reporting and building their own inventory according to EMEP guideline. As different countries applied different methodologies to build the new inventory, a detailed analysis is only possible on a country-by-country basis. This study will review the spatial distribution and differences for Europe but focus on Portugal for a more detailed analysis for total values and air quality simulations. 
The paper is organised as follows: in Section 2, the analysed emission inventories are described in detail and a comparison of emission data is performed. In Section 3, the modelling setup is presented. In Section 4, results from the air quality simulations are compared and quantified. Section 5 is dedicated to the validation of the model and statistical analysis of the simulations. Finally, in Section 6, the main conclusions are summarized.

\section{THE EMEP EMISSION INVENTORY}

\subsection{The old $\left(0.5 \times 0.5^{\circ}\right)$ and new $\left(0.1 \times 0.1^{\circ}\right)$ EMEP inventories}

While EMEP (emep.int) collects data to fulfil the goals of the LRTAP convention, emission inventories and projections are managed by the EMEP Task Force on Emission Inventories and Projections (TFEIP). Reported emissions and projections of acidifying air pollutants, heavy metals, particulate matter and photochemical oxidants are collected by CEIP. Recently, a new version of the EMEP inventory was made available, with a $0.1^{\circ} \times 0.1^{\circ}$ grid (E01), which is a horizontal resolution upgrade compared to the older $0.5^{\circ} \times 0.5^{\circ}$ version (E05). A significant difference between the two emission inventories should be highlighted, which concerns the inclusion and not inclusion of the (industrial) point. While E05 includes them in the cell value of their corresponding grid position, E01 provides these emissions in a separate file and does not include them in the gridded cell value. In Portugal, the Portuguese Environment Agency (APA) is the one responsible for compiling the data and building the EMEP inventory for the country. To build the new inventory, the same methodology as previous versions of E05 was applied to estimating the emissions, then the gridded emissions were downscaled to match the $0.1^{\circ} \times 0.1^{\circ}$ resolution.

\subsection{Analysis per sector and pollutant}

To understand how the different resolutions affect emission values, Figures 1 and 2 show the inventory maps regarding their spatial differences (E01 - E05) and absolute values, respectively. The data was plotted for the most important pollutants and specific sectors (transport, industry, residential combustion and agriculture). 
$\mathrm{NO}_{2}$ Transport (S7, S8)

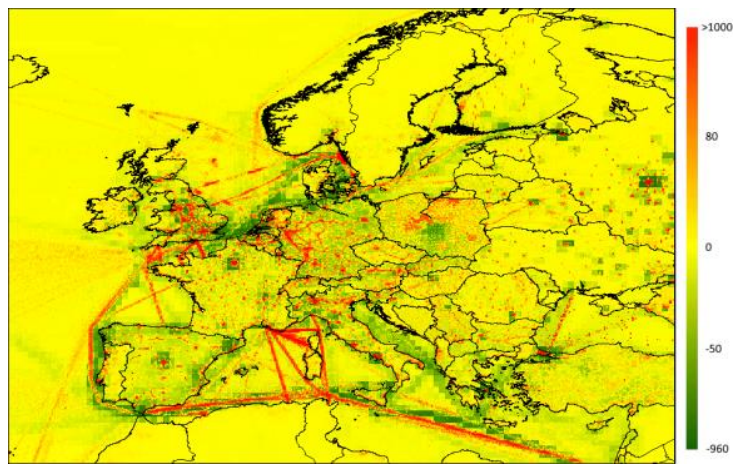

PM10 Residential combustion (S2)

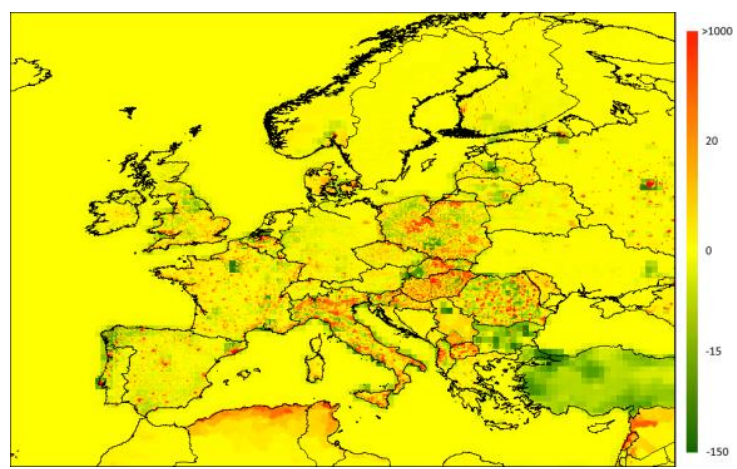

$\mathrm{NO}_{2}$ Industry $(\mathrm{S} 3, \mathrm{~S} 4)$

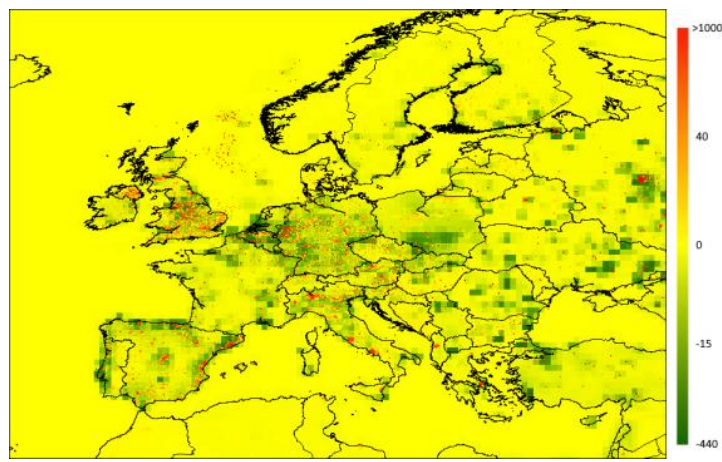

$\mathrm{NH}_{3}$ Agriculture (S10)

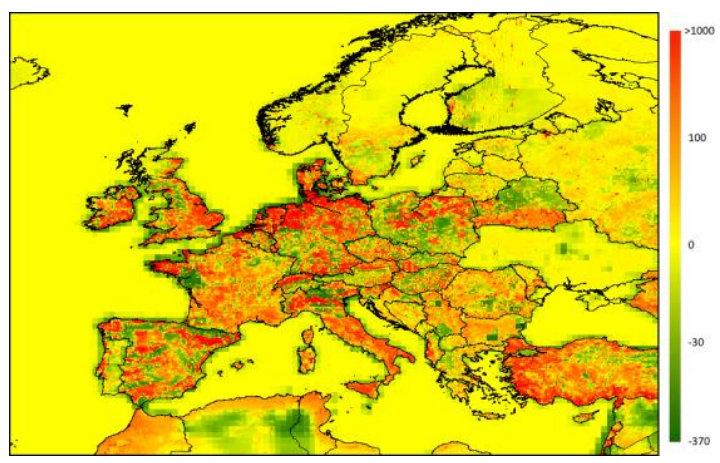

Figure 1 - Emissions delta, in t.yr-1 ${ }^{-1}$ between E01 $\left(0.1^{\circ} \times 0.1^{\circ}\right)$ and E05 $\left(0.5^{\circ} \times 0.5^{\circ}\right)$, for $\mathrm{NO}_{2}$,

PM10 and $\mathrm{NH}_{3}$ and sectors S2, S3/S4, S7/S8 and S10 (green E05>E01, red E01>E05).

First, the different deltas found over Europe can be justified by the different methodologies applied by each Member State for the updated EMEP inventory. There are countries where the deltas are mostly positive and others where it is negative. Additionally, there is the case of Turkey and North African region, where the deltas could indicate missing data.

Nevertheless, differences in $\mathrm{NO}_{2}$ emissions from the transport sectors (S7/S8) are largely focused in urban areas and shipping routes, while industrial sources (S3/S4) are concentrated in and around cities. Due to the more coarse resolution of E05, the E01 emission values are consistently higher in the centre of these areas, and lower further away from the centre. These hotspots are where the difference between the resolutions of the emissions data is most evident. Transport

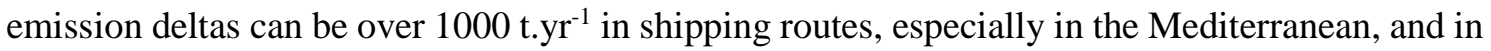
metropolitan areas throughout Europe. Industrial emission deltas are mainly focused in and near urban areas, which is generally the location of large industrial installations, with deltas in the 
same order of magnitude of S7/S8, which can represent approximately $75 \%$ of a grid cell value in this sector. Regarding PM10, the same conclusions from the $\mathrm{NO}_{2}$ industrial sector emissions can be applied. The differences are also focused in and around urban areas, which is to be expected

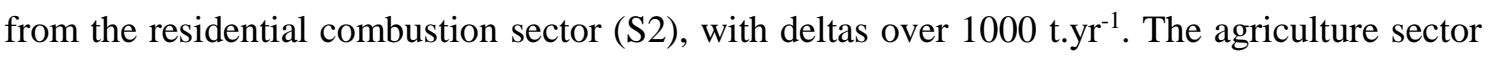
(S10) is where the spatial differences cover the biggest area, throughout almost every country in Europe, with large hotspots located over vast agricultural areas. The largest deltas for this sector are also over 1000 t.yr $^{-1}$. Although these differences are similar in absolute values, in relative terms, the differences in these sectors can represent up to 44\% (S7/S8), 75\% (S3/S4), 82\% (S2) and $97 \%$ (s10) of the total emission values in a grid cell, due to initial resolution differences alone. It is worth to note that for the studied pollutants the largest differences in the spatial distribution and in values do not occur in Portugal due to overall emissions being lower. Nonetheless, the

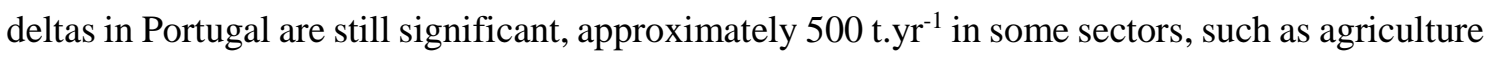
(S10).

In Portugal, there are noticeable differences between the inventories when it comes to total and per sector values, especially in urban areas, with lower values registered for E01 when compared to E05.

Figure 2 shows the total emissions of each inventory for the aforementioned sectors and pollutants, for Portugal.

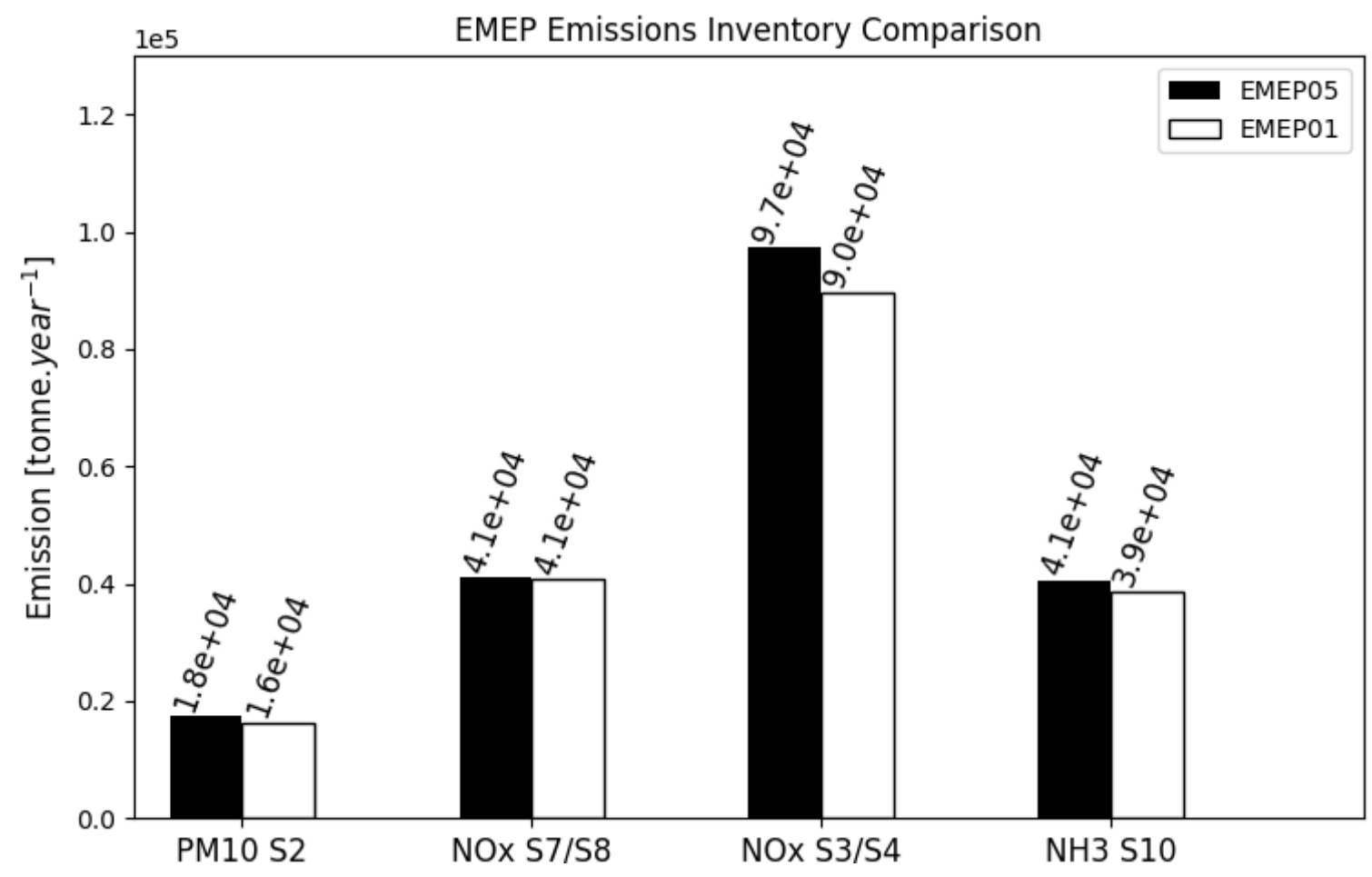


Figure 2 - Total emissions $\left(\mathrm{t}_{\mathrm{yr}} \mathrm{yr}^{-1}\right)$, for Portugal, of each inventory and each of the studied sector/pollutant pairs

Emission values present a negligible difference for the transport sectors (S7/S8), with noticeable differences for residential combustion (S2 - PM10, $0.2 \times 10^{4}$ t.yr-1) and agriculture (S10 - $\mathrm{NH}_{3}$, $0.2 \times 10^{4} \mathrm{t}_{\mathrm{yr}} \mathrm{r}^{-1}$ ). The largest difference is for industrial sources (S3/S4), where E01 has $0.7 \times 10^{4}$ t.yr ${ }^{-1}$ lower NOx emissions compared to E05, which could be due to the updated inventory (E01) not having point sources included in the gridded emissions. Even if these differences are small compared to total values, they may affect air quality simulations and the accuracy of modelled data, which is discussed in the following sections.

In terms of absolute values for Portugal, there are small differences between the totals of both inventories. These results confirm that the main differences between the two inventories, E01 and E05, will be associated to the spatial disaggregation, and not an update on emission values.

\section{AIR QUALITY MODELLING SETUP}

To evaluate the accuracy of each emissions inventory, an air quality modelling system was applied with high resolution simulations, using each of the inventories, and the resulting pollutant concentrations were compared between them and validated using observations.

To perform this evaluation, the WRF-CHIMERE modelling setup was used. WRF is the Weather Research \& Forecasting model, developed by the National Center for Atmospheric Research (NCAR) and is a mesoscale numerical model (Skamarock and Klemp 2008). CHIMERE is a chemistry transport model, in a non-hydrostatic configuration, with nesting capabilities, combining both high grid resolutions and the representation of large-scale transport processes and long-term simulations for emission control scenarios (Menut et al. 2013; Mailler et al. 2017). This system has been extensively applied for Europe, and Portugal in particular (Monteiro et al. 2007, 2018; Borrego et al. 2011), and is used for daily operational air quality forecast (http://previsaoqar.web.ua.pt/).

The emission data is pre-processed with the emiSURF program which generates anthropogenic surface emission data for CHIMERE air quality simulations. This program reads the annual inventory and performs a spatial allocation of surface emissions based on landuse data. Then, the annual data is distributed into the twelve months of the year based on seasonal factors, followed by a second temporal allocation according to the day of the week, and finally a 24-hour profile for each day of the week. This is done for each pollutant from each emission sector. 
The numerical air quality simulations were performed using three domains, using nesting capabilities, to obtain high resolutions simulations for Portugal. The first and largest domain encompasses the majority of Europe at a low horizontal resolution of $27 \times 27 \mathrm{~km}^{2}$ (CONT27), followed by an intermediate resolution of $9 \times 9 \mathrm{~km}^{2}$ (IP09) covering the Iberian Peninsula. The smallest and highest resolution domain is focused on Portugal, with a $3 \times 3 \mathrm{~km}^{2}$ (PT03) horizontal resolution.

Further details regarding the model setup and the simulations performed, such as vertical resolution, parametrizations and boundary conditions can be found summarized in Table 1 .

Table 1. WRF and CHIMERE specifications

WRF (version 3.5.0)

\begin{tabular}{|c|c|}
\hline Microphysics & WSM6 scheme (Hong and Lim 2006) \\
\hline Cumulus parametrizations & Kain-Fritsch scheme (Kain and Kain 2004) \\
\hline Planetary boundary layer & ACM2 scheme (Pleim 2007) \\
\hline Atmospheric radiation & RRTMG scheme (Iacono et al. 2008) \\
\hline Grid-nesting techniques & One-way interactive \\
\hline \multicolumn{2}{|c|}{ CHIMERE (version 2016a1) } \\
\hline Emissions inventory & EMEP $2015\left(0.5^{\circ} \times 0.5^{\circ}\right.$ and $0.1^{\circ} \times 0.1^{\circ}$ grids $)$ \\
\hline Chemistry mechanism & Melchior reduced \\
\hline Chemically-active aerosols & Yes \\
\hline Number of aerosol size sections & 10 \\
\hline Horizontal and vertical advection schemes & Van Leer I \\
\hline Number of vertical layers & 24 \\
\hline Top layer pressure & $200 \mathrm{hPa}$ \\
\hline Radiative processes & Fast-JX model \\
\hline Boundary conditions & LMDz-INCA (gaseous and particular species) \\
\hline
\end{tabular}

Due to computational limitations and the extended time required to run the modelling setup, two months were chosen to perform the study, one in the summer (June) and another in the winter (December). Different seasons typically have characteristic main emission sources and distinct synoptic conditions, which result in different air quality issues. During winter, for example, residential wood combustion is an important source of atmospheric pollutants (Carvalho et al. 2009). The combination of greater PM emissions during winter, in urban areas, with thinner and 
more stable atmospheric boundary layers results in higher monthly mean PM concentrations in winter than in summer (Gama et al. 2018). During summer, the typical anticyclonic conditions with associated high air temperatures and high irradiation favours the occurrence of photochemical pollution episodes, with high ozone concentrations (Borrego et al. 2016).

\section{ANALYSIS OF AIR QUALITY MODELLING RESULTS}

\subsection{Spatial Differences}

Figure 3 shows the spatial distribution of the differences (mean and maximum deltas, E01 - E05) found between the hourly simulations made with each of the inventories, for the European domain and for the studied pollutants $\left(\mathrm{NO}_{2}, \mathrm{PM} 10\right.$ and $\left.\mathrm{O}_{3}\right)$. $\mathrm{NH}_{3}$ was not considered in the following sections due to observations for this pollutant not being available. The results for this section consider the entire simulation period (June + December).

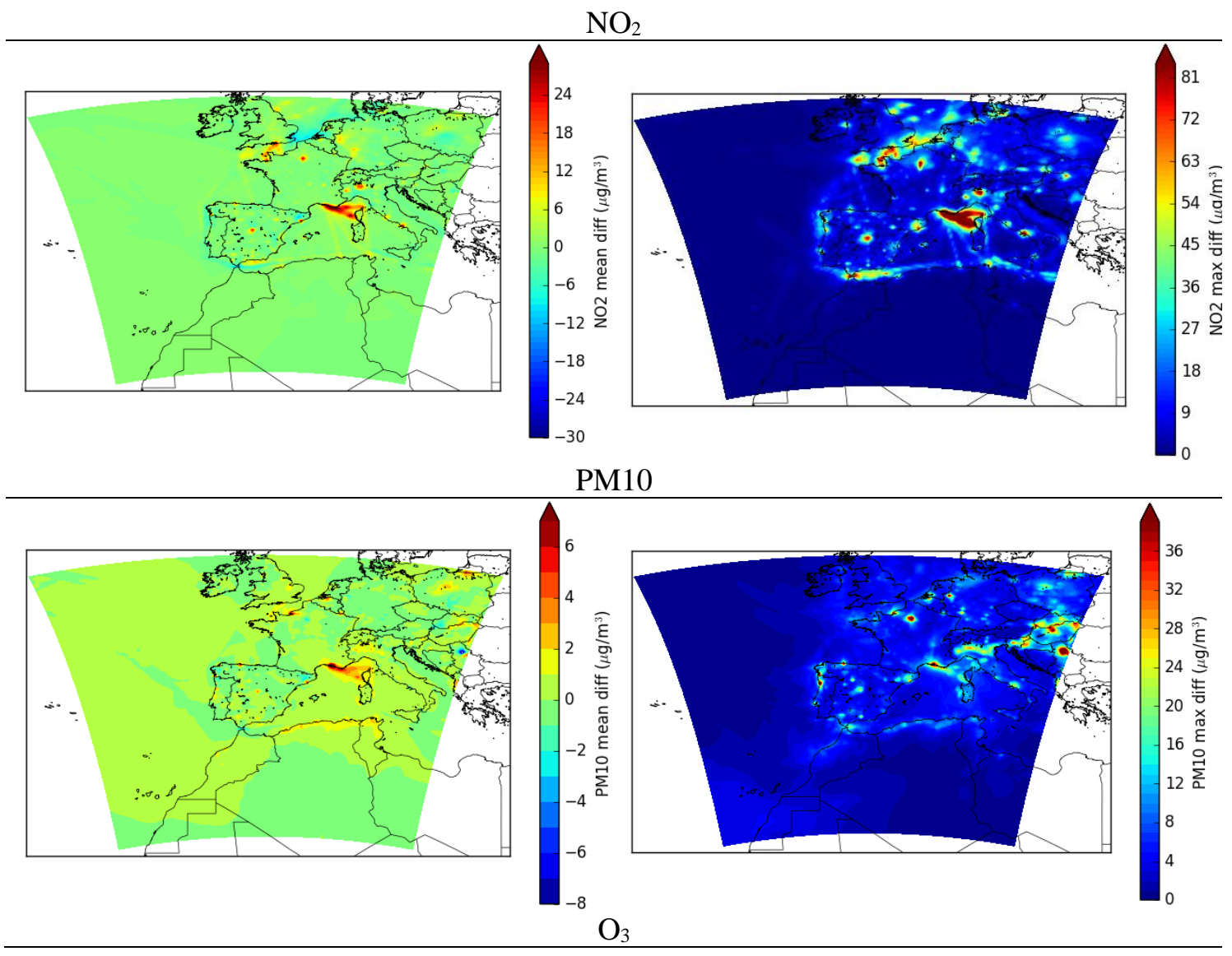




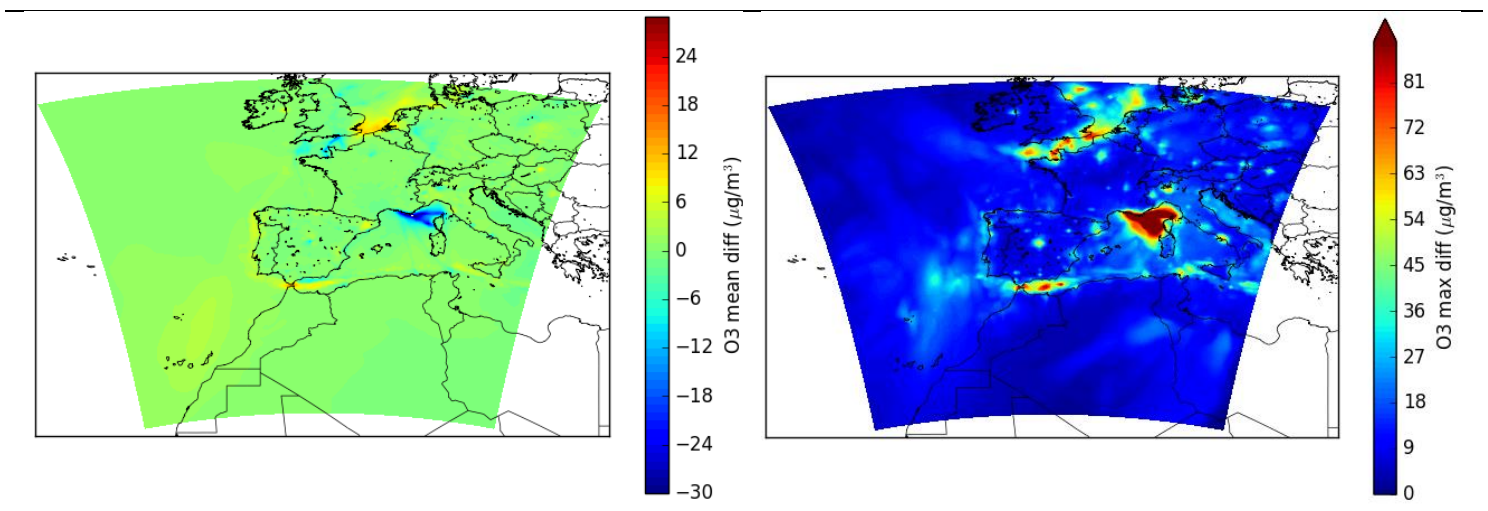

Figure 3 - Mean deltas (left) and maximum deltas (right) between the simulations, E01 - E05, for $\mathrm{NO}_{2}, \mathrm{PM} 10$, and $\mathrm{O}_{3}$ concentrations, for the European domain (CONT27)

Over the European domain, the largest deltas for $\mathrm{NO}_{2}, \mathrm{PM} 10$ and $\mathrm{O}_{3}$ are over international shipping routes and metropolitan areas. Maximum deltas are above $80 \mu \mathrm{g} . \mathrm{m}^{-3}$ for $\mathrm{NO}_{2} ; 35 \mu \mathrm{g} . \mathrm{m}^{-}$ ${ }^{3}$ for $\mathrm{PM} 10$, and $80 \mu \mathrm{g} \cdot \mathrm{m}^{-3}$ for $\mathrm{O}_{3}$. Regarding the mean differences, they reach $25 \mu \mathrm{g} \cdot \mathrm{m}^{-3}$ for $\mathrm{NO}_{2}$; $7 \mu \mathrm{g} \cdot \mathrm{m}^{-3}$ for PM10, and $25 \mu \mathrm{g} \cdot \mathrm{m}^{-3}$ for $\mathrm{O}_{3}$. These mean deltas are of the same order of magnitude as the annual average concentrations observed in these areas (European Environment Agency 2017), which means that the deltas found between the two EMEP inventories can be highly significant.

Figure 4 shows a similar analysis for Portugal domain.

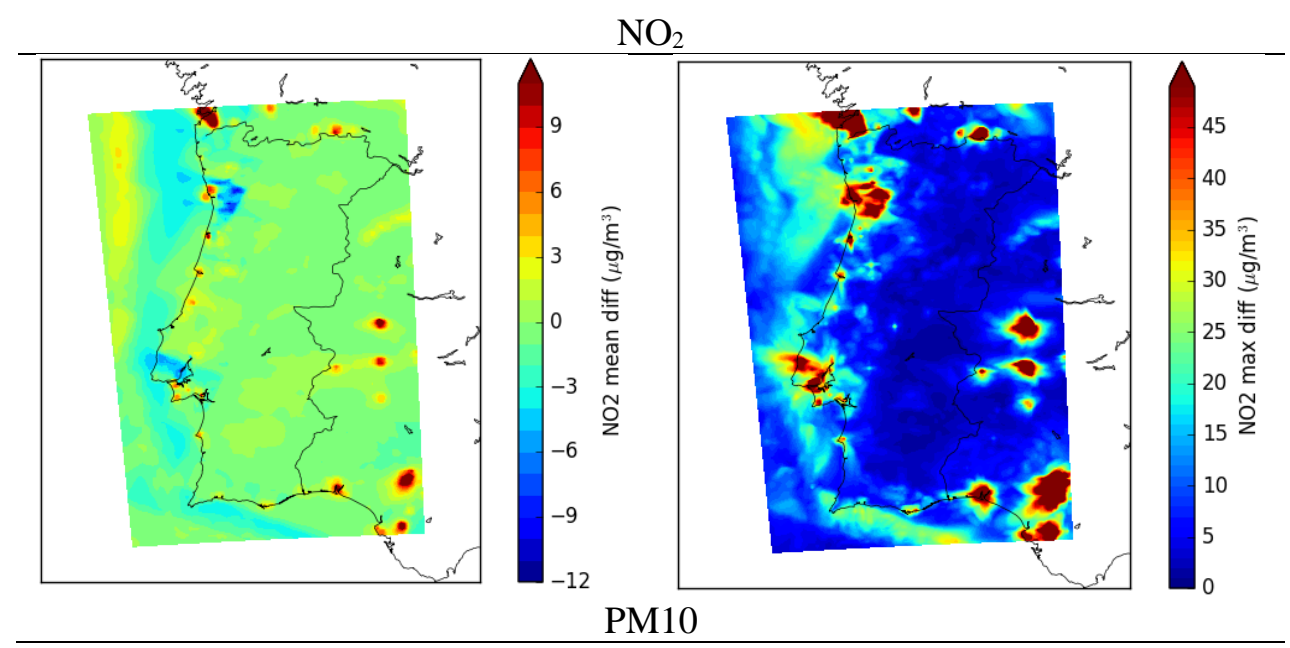




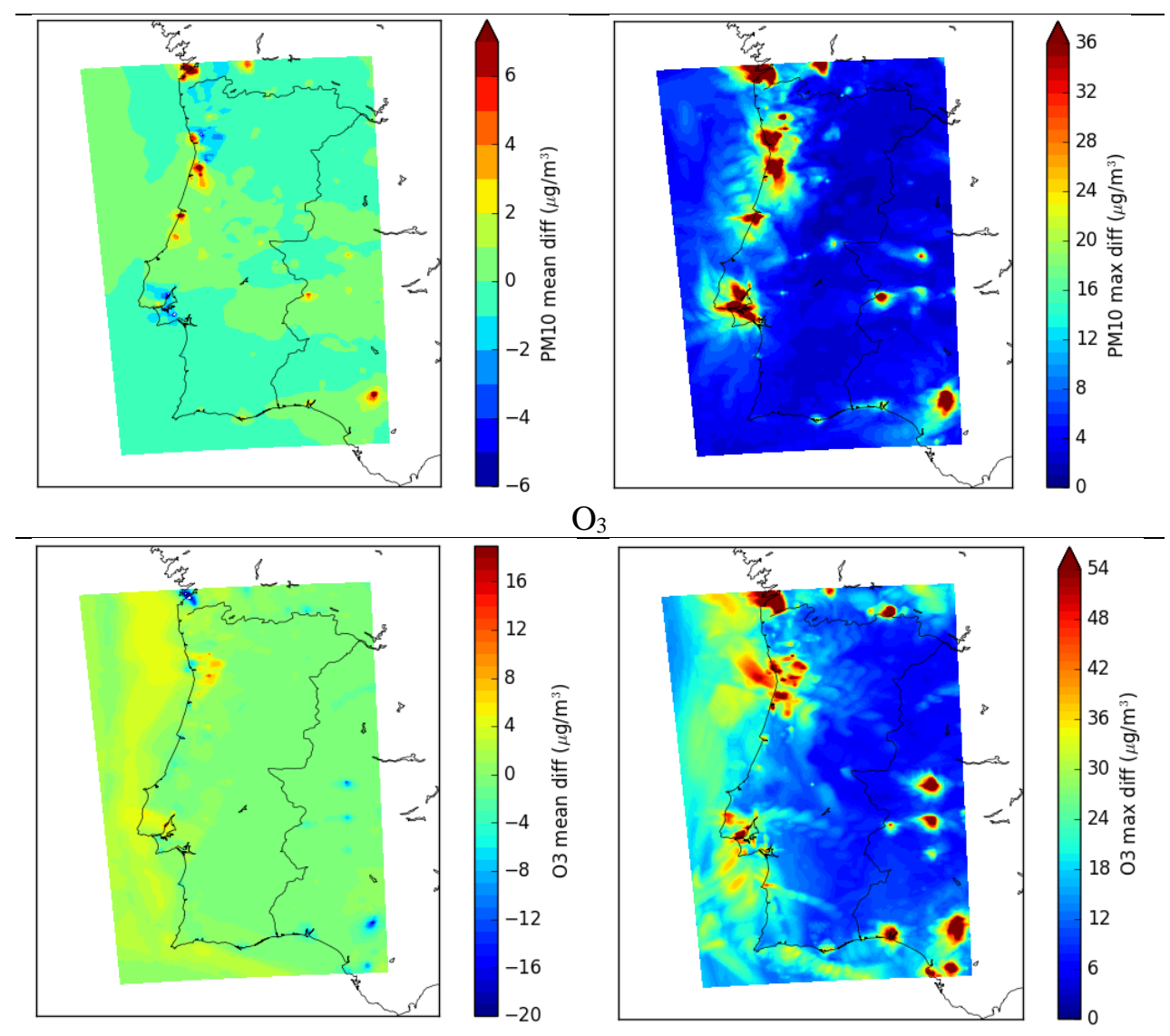

Figure 4 - Mean deltas (left) and maximum deltas (right) between the simulations, E01 - E05, for $\mathrm{NO}_{2}, \mathrm{PM} 10$ and $\mathrm{O}_{3}$ concentrations, for the Portuguese domain (PT03)

Focusing on Portugal, the main conclusions addressed for Europe still apply. Regarding $\mathrm{NO}_{2}$, the areas with the highest differences are cities and shipping routes (including some ports). Maximum differences for $\mathrm{NO}_{2}$ are above $45 \mu \mathrm{g} . \mathrm{m}^{-3}$, and mean differences are in the $10 \mu \mathrm{g} . \mathrm{m}^{-3}$ range, over the Porto and Lisbon metropolitan areas (where the magnitude of $\mathrm{NO}_{2}$ mean levels is around 10 - $50 \mu \mathrm{g} \cdot \mathrm{m}^{-3}$, see Figure 4). PM10 deltas have a similar distribution to $\mathrm{NO}_{2}$ although mostly concentrated in larger urban areas, where the maximum differences are over $36 \mu \mathrm{g} \cdot \mathrm{m}^{-3}$ and average $6 \mu \mathrm{g} \cdot \mathrm{m}^{-3}$ (observations are in the range of $10-30 \mu \mathrm{g} \cdot \mathrm{m}^{-3}$ ). $\mathrm{O}_{3}$ deltas located away from $\mathrm{NO}_{2}$ hotspots are due to the secondary photochemical origin of $\mathrm{O}_{3}$, with average values of 16 $\mu \mathrm{g} . \mathrm{m}^{-3}$ and maximums of $54 \mu \mathrm{g} . \mathrm{m}^{-3}$ (observed maximum values are around $25-120 \mu \mathrm{g} \cdot \mathrm{m}^{-3}$ ).

\subsection{Model validation}

To better evaluate and quantify the performance of each inventory, the simulated results were compared to the observations data from the Portuguese air quality monitoring network. Since there are numerous stations throughout the country, an average value for each station type was considered to aid in the comparison of the results obtained with each inventory and are shown in Figures 6 through 8. Only background stations (urban, suburban and rural, Figure 5) are 
considered due to their concentration values not being significantly influenced by any specific source, but rather a combination of all upwind sources in the surrounding areas. Daily averages $\left(\mathrm{NO}_{2}\right.$ and PM10) and daily maximum values $\left(\mathrm{O}_{3}\right)$ were considered. Later in this section, the calculated statistical parameters are shown.

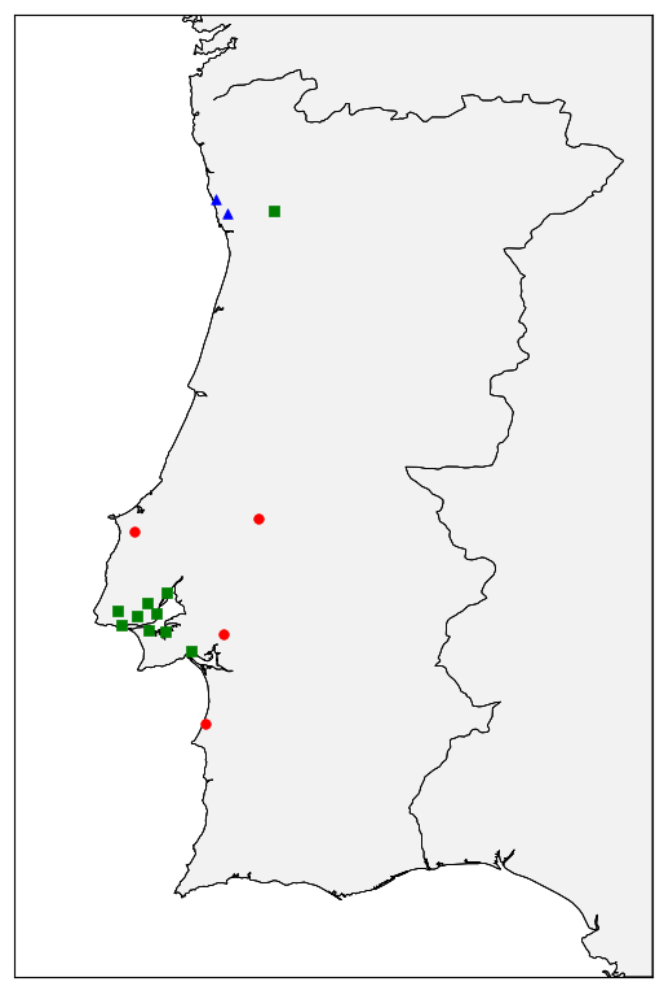

Figure 5 - Background air quality monitoring station locations considered for the study (urban green squares; suburban - blue triangles; rural - red circles)

Urban

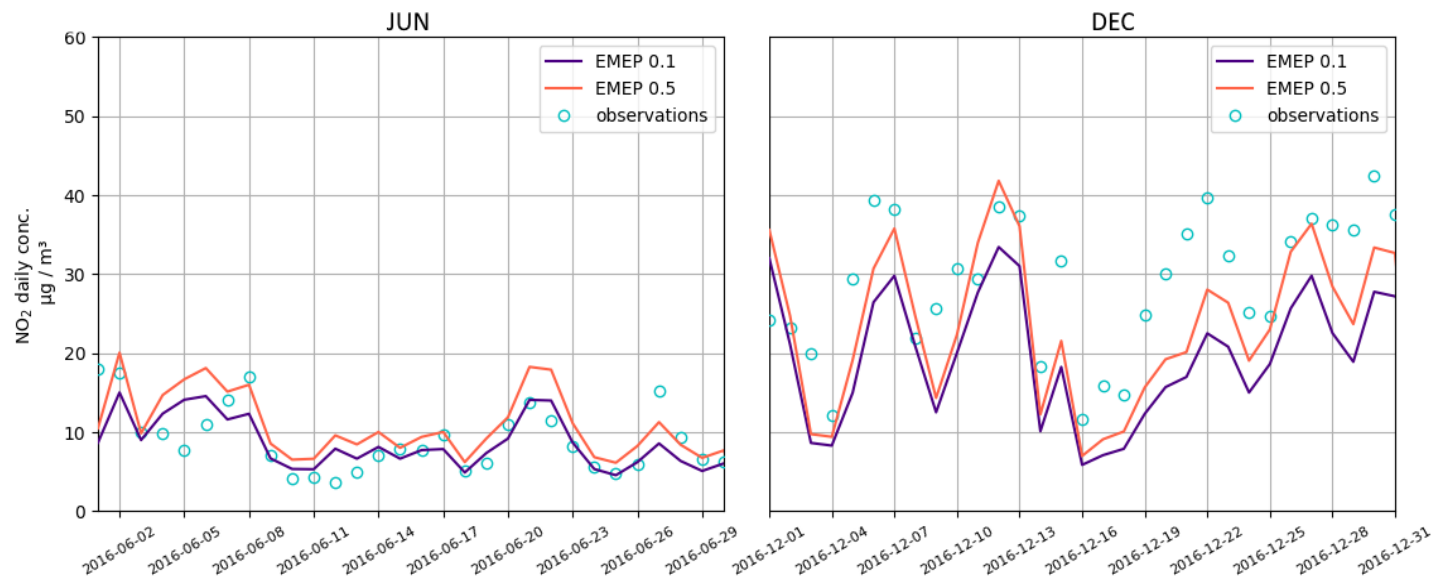


Suburban

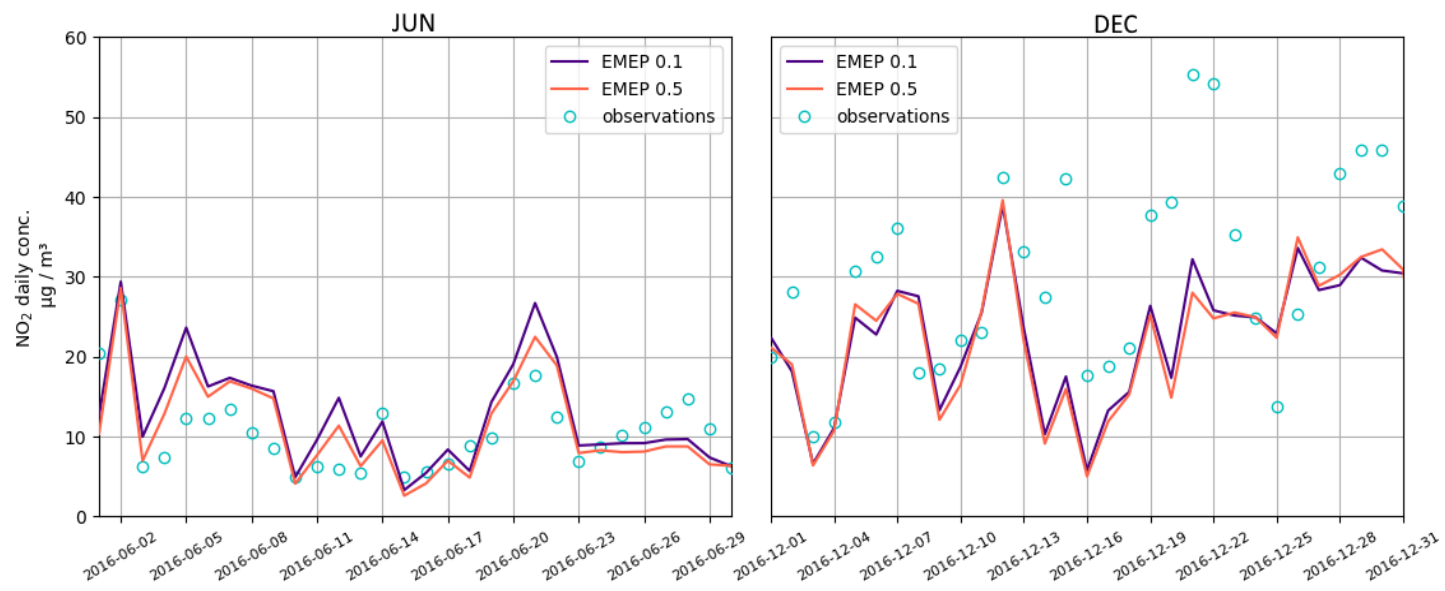

Rural
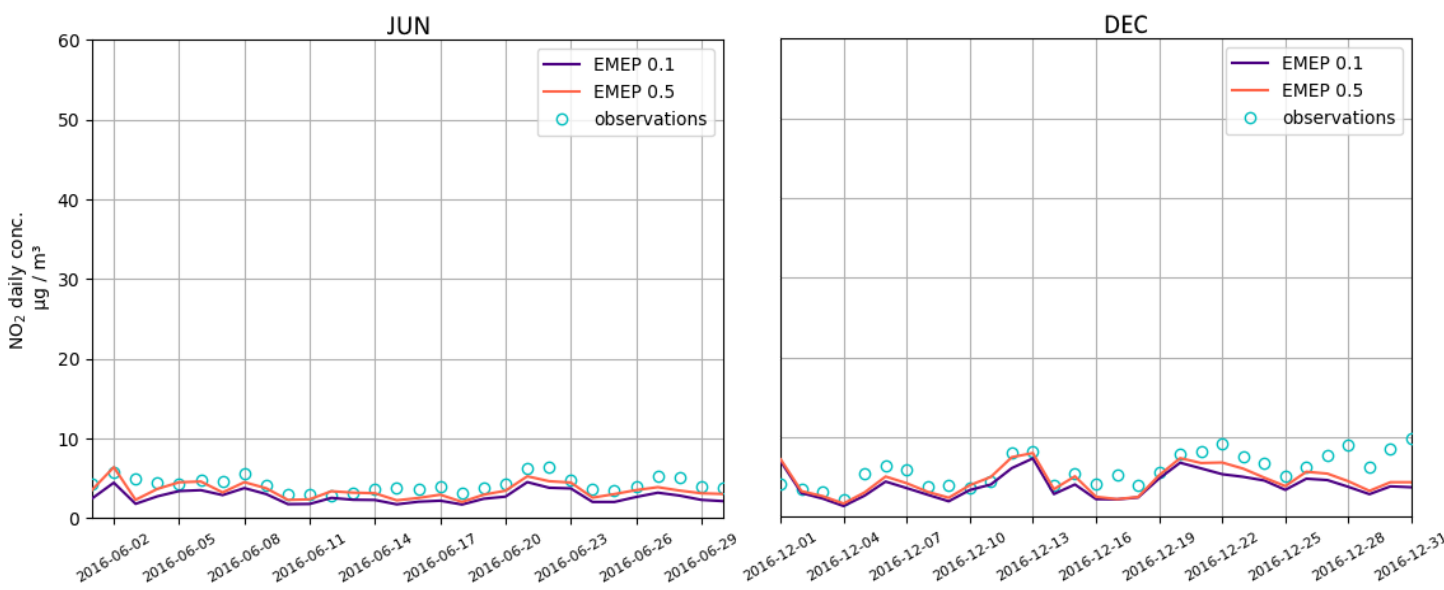

Figure 6 - Daily average $\mathrm{NO}_{2}$ time series per air quality monitoring station type (E05 in orange, E01 in indigo and observed data in light blue circles).

\section{Urban}

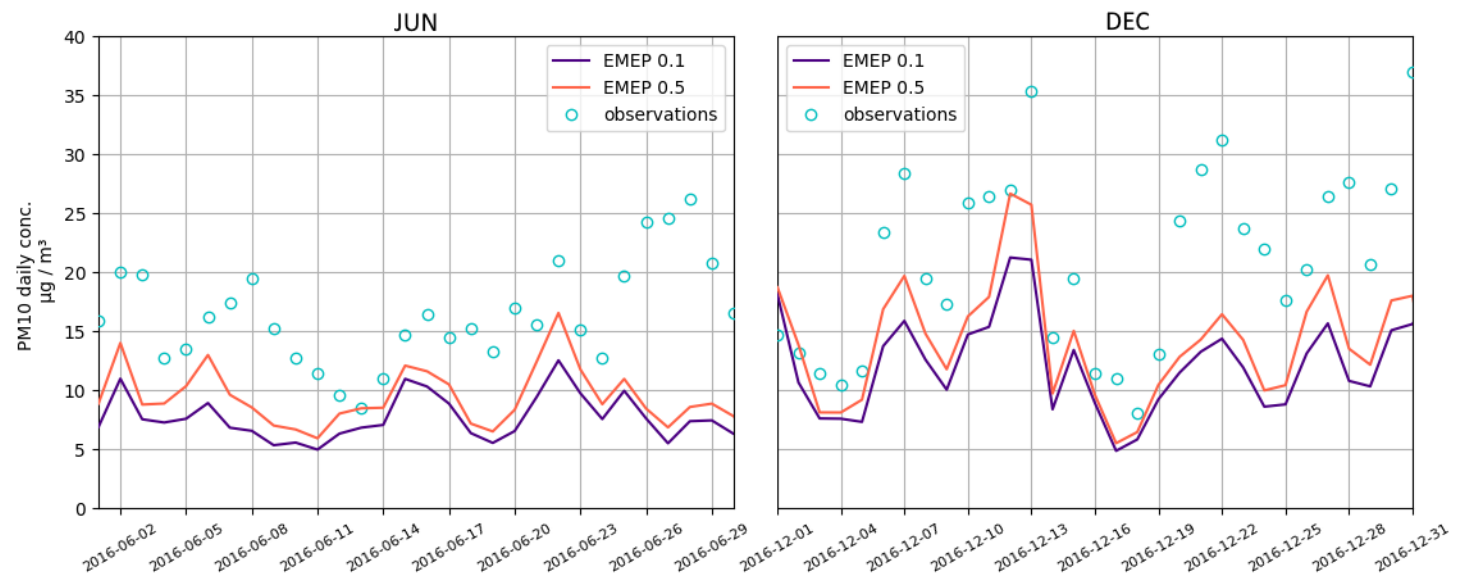


Suburban
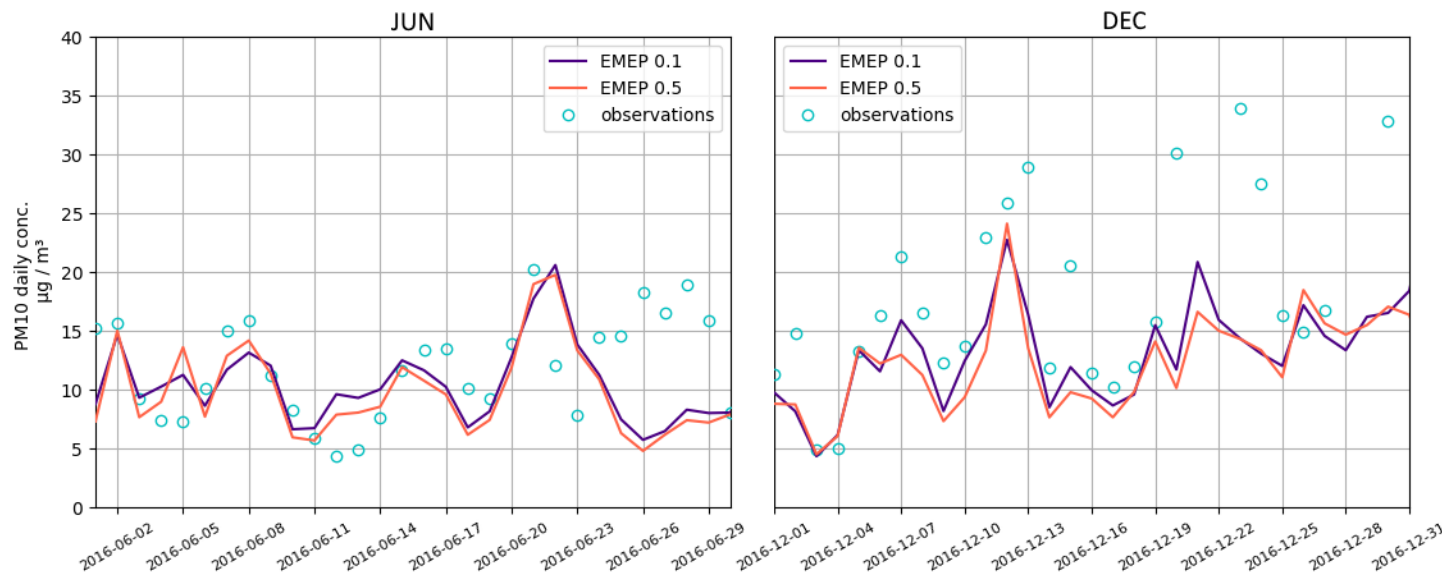

Rural

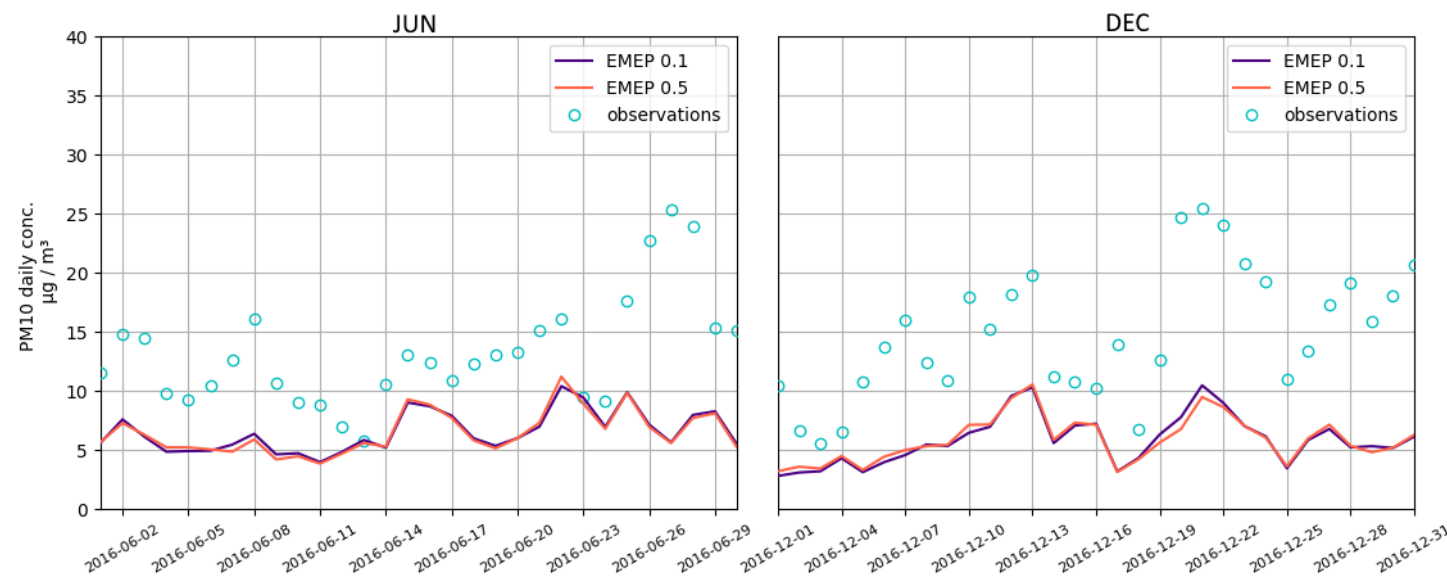

Figure 7 - Daily average PM10 time series per air quality monitoring station type (E05 in orange, E01 in indigo and observed data in light blue circles).

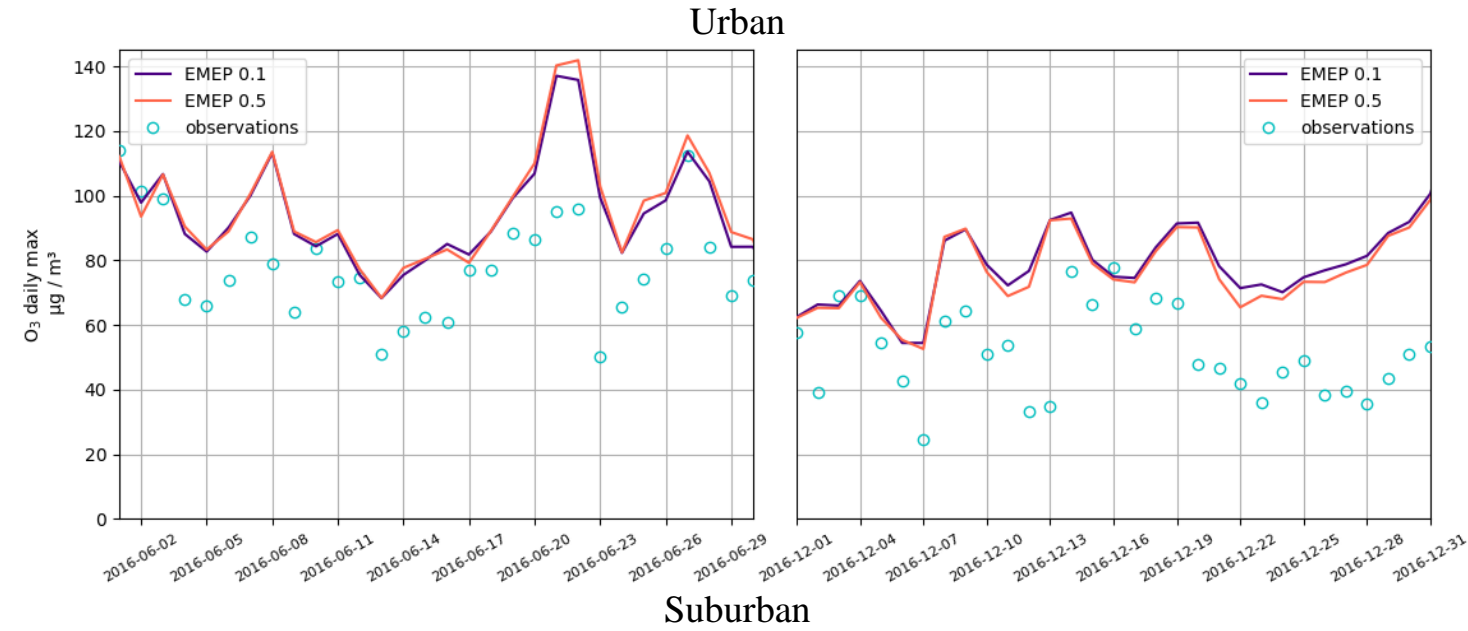



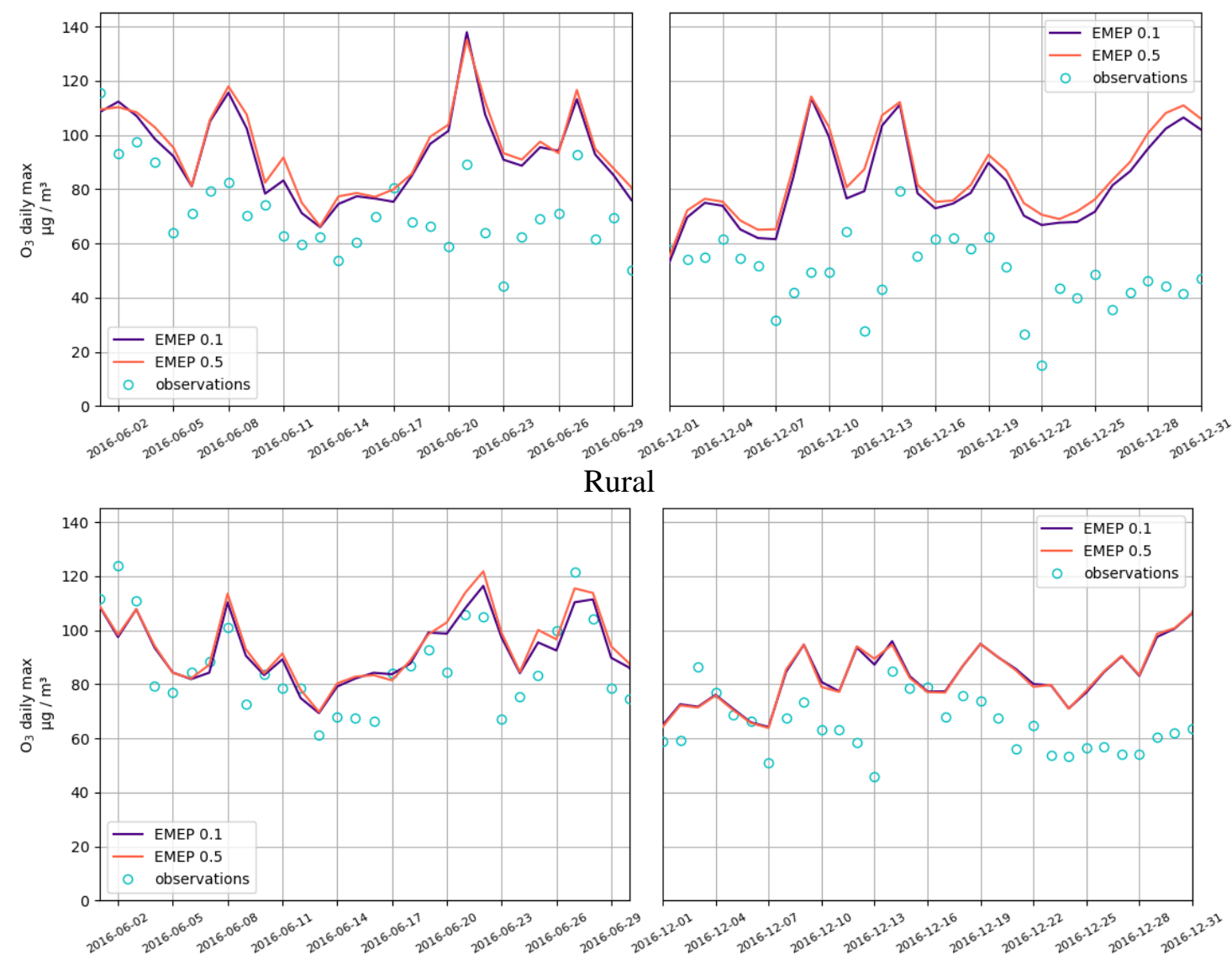

Figure $8-\mathrm{O}_{3}$ maximum daily time series per air quality monitoring station type (E05 in orange,

E01 in indigo and observed data in light blue circles).

The times series analysis shows an overall good model performance, with $\mathrm{NO}_{2}$ and $\mathrm{O}_{3}$ having the best match between observed and modelled values, although there is an overestimation of $\mathrm{O}_{3}$, particularly in suburban stations. In the case of PM10, the model underperforms when simulating PM10 concentrations (Figure 7), which is to be expected. Many studies have recognized the difficulty in modelling this pollutant (Matthias 2008; Pay et al. 2010). As summarized by Basart et al. (2012), the underestimation of PM10 may be related with the lack of fugitive dust emissions and resuspended matter, as well as inaccurate or not considered sources in the emission inventory. Regarding the inventories, similarities are found for every pollutant. Nevertheless, there is evidence of higher accuracy when using the coarse E05 inventory in urban and rural observations, which was not expected since E01 should better represent urban land use due to its higher resolution. However, as previously mentioned, the new grid was only downscale from the older, more coarse, E05 gridded emissions. Nonetheless, in suburban stations, E01 achieves better results. 
To better understand and compare the different results from the simulations, statistical parameters were calculated to evaluate the accuracy of the model when using each of the inventories. Statistical metrics were chosen and calculated according to Borrego et al. (2008) (Table 2).

Table 2 - Statistical model quality indicators used in this study.

\begin{tabular}{ccc} 
Parameter & Name & Formula \\
\hline $\mathrm{R}$ & Pearson correlation coefficient & $\mathrm{R}=\frac{\overline{\mathrm{Oi}-\overline{\mathrm{Oi}} \mid \overline{\mathrm{Ei}}-\overline{\mathrm{Ei}}}}{\sigma_{{ }_{c_{E}} \sigma_{c_{O}}}}$ \\
IOA & Index of agreement & $\mathrm{IOA}=1-\frac{\sum(\mathrm{Ei}-\mathrm{Oi})^{2}}{\sum(|\mathrm{Ei}-\overline{\mathrm{Oi}}|+|\mathrm{Oi}-\overline{\mathrm{Oi}}|)^{2}}$ \\
RMSE & Root mean squared error & $\mathrm{RMS}=\sqrt{\overline{(\mathrm{Oi}-\mathrm{Ei})^{2}}}$ \\
\hline bias & Mean relative bias & bias $=\overline{\mathrm{O} i-\overline{\mathrm{Ei}}}$ \\
\hline
\end{tabular}

The correlation coefficient, $\mathrm{R}$, measures the strength of the linear relationship between predicted and observed concentrations. However, as it is insensitive to either an additive or a multiplicative factor, an $\mathrm{R}$ value of 1.0 is not a sufficient condition for a model to be considered accurate. The index of agreement, IOA, proposed by Willmott (1981), can be seen as an alternative to R, although it is not a measure of correlation in its formal sense, it reflects the degree of accuracy of the estimated variable. Unlike R, IOA can detect additive and proportional differences in the observed and simulated means and variances. A model that would show a perfect agreement with the observations would have an IOA of 1.0. The root mean square error (RMSE) provides the mean relative scatter of the modelled values, indicating both systematic and random errors. Mean relative bias indicates only systematic errors, the calculated value of this metric depend only on the average of the predicted and observed concentrations. Chang and Hanna (2004) highlight that it is possible for a model to have predictions completely out of phase of observations and still have an ideal bias value $(0.0)$, due to cancelling errors.

These metrics were calculated for the entire study period and the results are presented in Table 3, organized in terms of average values per station type and for each of the EMEP inventories and pollutants. Hourly data for $\mathrm{NO}_{2}$ and $\mathrm{O}_{3}$ was considered, and daily averages for PM10. 
Table 3 - Average statistical parameters for each type of air quality monitoring stations and each EMEP inventory

\begin{tabular}{|c|c|c|c|c|c|c|}
\hline & \multicolumn{2}{|c|}{ Urban } & \multicolumn{2}{|c|}{ Suburban } & \multicolumn{2}{|c|}{ Rural } \\
\hline & E05 & E01 & E05 & E01 & E05 & E01 \\
\hline \multicolumn{7}{|c|}{$\mathrm{R}$} \\
\hline $\mathrm{NO}_{2}$ & 0.66 & 0.66 & 0.64 & 0.62 & 0.53 & 0.52 \\
\hline PM10 & 0.59 & 0.60 & 0.47 & 0.50 & 0.40 & 0.44 \\
\hline $\mathrm{O}_{3}$ & 0.69 & 0.67 & 0.60 & 0.62 & 0.62 & 0.61 \\
\hline \multicolumn{7}{|c|}{ IOA } \\
\hline $\mathrm{NO}_{2}$ & 0.79 & 0.76 & 0.76 & 0.74 & 0.64 & 0.60 \\
\hline PM10 & 0.64 & 0.58 & 0.54 & 0.56 & 0.47 & 0.48 \\
\hline $\mathrm{O}_{3}$ & 0.72 & 0.69 & 0.59 & 0.64 & 0.65 & 0.63 \\
\hline \multicolumn{7}{|c|}{ RMSE } \\
\hline $\mathrm{NO}_{2}$ & 13.00 & 13.82 & 15.76 & 16.61 & 3.63 & 3.88 \\
\hline PM10 & 9.59 & 11.11 & 8.05 & 7.91 & 9.30 & 9.24 \\
\hline $\mathrm{O}_{3}$ & 25.89 & 27.55 & 34.83 & 30.42 & 24.67 & 25.17 \\
\hline \multicolumn{7}{|c|}{ bias } \\
\hline $\mathrm{NO}_{2}$ & -1.77 & -4.97 & -4.10 & -3.21 & -1.10 & -1.78 \\
\hline PM10 & -6.75 & -8.57 & -4.03 & -3.46 & -7.73 & -7.73 \\
\hline $\mathrm{O}_{3}$ & 18.38 & 20.47 & 29.16 & 23.21 & 18.16 & 18.62 \\
\hline
\end{tabular}

Overall, the analysis of the statistical parameters confirms that E05 has a higher accuracy in terms of air quality modelling results, which means a higher resolution in the input data does not necessarily result in a better representation of the emission data. While there were no significant differences found in the correlation factor, because the same time profiles are applied for both inventories, for the RMSE and bias, large differences are found for urban and suburban stations.

\section{CONCLUSIONS}

The specifications of the EMEP emissions inventory has changed, from grid cells of $0.5^{\circ} \times 0.5^{\circ}$ to a higher resolution grid $\left(0.1^{\circ} \times 0.1^{\circ}\right)$. Member States had to prepare this new grid according to EU requirements under the CLRTAP protocol, each using their own methodology. The purpose of this study was to investigate the main differences found between these two emissions inventories for Europe, focusing on Portugal as a case study, using the available common year (2015). Emission deltas were analysed per sector and pollutant, and both inventories were used for air quality modelling applications (using an already extensively validated air quality modelling system). The results found highlight major differences founded in several MS. Portugal was not one of the hotspots in the emissions delta maps but there were still significant differences found, mainly in the spatial distribution of shipping and agriculture emissions, as well as PM10 and NOx 
values. The analysis of the air quality modelling outputs, and their comparison with observed values, indicates that EMEP0.1 does not improve model performance over Portugal, suggesting that the higher resolution inventory was not built using the most appropriate methodology. This work highlights the importance in estimating the uncertainty associated to emission data, and confirms what other studies have already pointed out, that improving emission data resolution does not necessarily imply higher accuracy in modelling results, in particular for air quality modelling purposes. The authors recommend that each MS perform a similar study, to analyse their specific methodology and emission data, before using the new high-resolution EMEP inventory.

\section{ACKNOWLEDGEMENTS}

Thanks are due for the financial support to CESAM (UID/AMB/50017/2019), to FCT/MCTES through national funds. This work is a contribution to project AIRSHIP (PTDC/AAGMAA/2569/2014 - POCI-01-0145-FEDER-016752) funded by FEDER, through COMPETE2020

- Programa Operacional.

\section{REFERENCES}

Basart S, Pay MT, Jorba O, et al (2012) Aerosols in the CALIOPE air quality modelling system: Evaluation and analysis of PM levels, optical depths and chemical composition over Europe. Atmos Chem Phys 12:3363-3392. doi: 10.5194/acp-12-3363-2012

Borrego C, Monteiro A, Ferreira J, et al (2008) Procedures for estimation of modelling uncertainty in air quality assessment. Environ Int 34:613-620. doi: 10.1016/j.envint.2007.12.005

Borrego C, Monteiro A, Martins H, et al (2016) Air quality plan for ozone: an urgent need for North Portugal. Air Qual Atmos Heal 9:447-460. doi: 10.1007/s11869-015-0352-5

Borrego C, Monteiro A, Pay MT, et al (2011) How bias-correction can improve air quality forecasts over Portugal. Atmos Environ 45:6629-6641. doi:

10.1016/j.atmosenv.2011.09.006

Briggs DJ (1995) Environmental statistics for environmental policy: Genealogy and data quality. J Environ Manage 44:39-54. doi: 10.1006/jema.1995.0029

Carvalho A, Miranda AI, Valente J, et al (2009) Contribution of residential wood combustion to PM10 levels in Portugal. Atmos Environ 44:642-651. doi:

10.1016/j.atmosenv.2009.11.020 
Chang JC, Hanna SR (2004) Air quality model performance evaluation. Meteorol Atmos Phys 87:167-196. doi: 10.1007/s00703-003-0070-7

Davidson EA, Kanter D (2014) Inventories and scenarios of nitrous oxide emissions. Environ Res Lett 9:. doi: 10.1088/1748-9326/9/10/105012

European Environment Agency (2017) Air quality in Europe — 2017 report

Gama C, Monteiro A, Pio C, et al (2018) Temporal patterns and trends of particulate matter over Portugal: a long-term analysis of background concentrations. Air Qual Atmos Heal 11:397-407. doi: 10.1007/s11869-018-0546-8

Hong S-Y, Lim J-OJ (2006) The WRF single-moment 6-class microphysics scheme (WSM6). J Korean Meteor Soc 42:129-151

Iacono MJ, Delamere JS, Mlawer EJ, et al (2008) Radiative forcing by long-lived greenhouse gases: Calculations with the AER radiative transfer models. J Geophys Res Atmos 113:. doi: 10.1029/2008JD009944

Kain JS, Kain J (2004) The Kain - Fritsch convective parameterization: An update

Kuenen JJP, Visschedijk AJH, Jozwicka M, Denier Van Der Gon HAC (2014) TNO-MACC-II emission inventory; A multi-year (2003-2009) consistent high-resolution European emission inventory for air quality modelling. Atmos Chem Phys 14:10963-10976. doi: 10.5194/acp-14-10963-2014

La Notte A, Tonin S, Lucaroni G (2018) Assessing direct and indirect emissions of greenhouse gases in road transportation, taking into account the role of uncertainty in the emissions inventory. Environ Impact Assess Rev 69:82-93. doi: 10.1016/j.eiar.2017.11.008

Lindley SJ, Conlan DE, Raper DW, Watson AFR (2000) Uncertainties in the compilation of spatially resolved emission inventories - Evidence from a comparative study. Atmos Environ 34:375-388. doi: 10.1016/S1352-2310(99)00325-8

Mailler S, Menut L, Khvorostyanov D, et al (2017) CHIMERE-2017: From urban to hemispheric chemistry-transport modeling. Geosci Model Dev 10:2397-2423. doi: 10.5194/gmd-10-2397-2017

Matthias V (2008) The aerosol distribution in Europe derived with the Community Multiscale Air Quality (CMAQ) model: Comparison to near surface in situ and sunphotometer measurements. Atmos Chem Phys 8:5077-5097. doi: 10.5194/acp-8-5077-2008

Menut L, Bessagnet B, Khvorostyanov D, et al (2013) CHIMERE 2013: a model for regional atmospheric composition modelling. Geosci Model Dev 6:981-1028. doi: 10.5194/gmd-6981-2013 
Milne AE, Glendining MJ, Bellamy P, et al (2014) Analysis of uncertainties in the estimates of nitrous oxide and methane emissions in the UK's greenhouse gas inventory for agriculture. Atmos Environ 82:94-105. doi: 10.1016/j.atmosenv.2013.10.012

Mobely and Saeger (1996) Procedures for verification of emissions inventories

Monteiro A, Miranda AI, Borrego C, et al (2007) Long-term assessment of particulate matter using CHIMERE model. Atmos Environ 41:7726-7738. doi:

10.1016/j.atmosenv.2007.06.008

Monteiro A, Russo M, Gama C, Borrego C (2018) How important are maritime emissions for the air quality: At European and national scale. Environ Pollut 242:565-575. doi: 10.1016/j.envpol.2018.07.011

Pacyna JM, Graedel TE (1995) Atmospheric Emissions Inventories: Status and Prospects. Annu Rev Energy Environ 20:265-300. doi: 10.1146/annurev.eg.20.110195.001405

Pay MT, Piot M, Jorba O, et al (2010) A full year evaluation of the CALIOPE-EU air quality modeling system over Europe for 2004. Atmos Environ 44:3322-3342. doi: 10.1016/j.atmosenv.2010.05.040

Pisoni E, Albrecht D, Mara TA, et al (2018) Application of uncertainty and sensitivity analysis to the air quality SHERPA modelling tool. Atmos Environ 183:84-93. doi: 10.1016/j.atmosenv.2018.04.006

Pleim JE (2007) A combined local and nonlocal closure model for the atmospheric boundary layer. Part I: Model description and testing. J Appl Meteorol Climatol 46:1383-1395. doi: 10.1175/JAM2539.1

Quilcaille Y, Gasser T, Ciais P, et al (2018) Environmental Research Letters Uncertainty in projected climate change arising from uncertain fossil-fuel emission factors Uncertainty in projected climate change arising from uncertain fossil-fuel emission factors. Environ Res Lett 13:. doi: 10.1088/1748-9326/aab304

Skamarock WC, Klemp JB (2008) A time-split nonhydrostatic atmospheric model for weather research and forecasting applications. J Comput Phys 227:3465-3485. doi: 10.1016/j.jcp.2007.01.037

Willmott CJ (1981) On the Validation of Model

Winiwarter W, Rypdal K (2001) Assessing the uncertainty associated with national greenhouse gas emission inventories: Atmos Environ 35:5425-5440. doi: 10.1016/S13522310(01)00171-6

Zachariadis T, Samaras Z (1997) Comparative assessment of European tools to estimate traffic 
emissions. Int J Veh Des 18:312-325. doi: 10.1504/IJVD.1997.062056

Zheng B, Zhang Q, Tong D, et al (2017) Resolution dependence of uncertainties in gridded emission inventories: A case study in Hebei, China. Atmos Chem Phys 17:921-933. doi: 10.5194/acp-17-921-2017

Zheng J, Zhang L, Che W, et al (2009) A highly resolved temporal and spatial air pollutant emission inventory for the Pearl River Delta region, China and its uncertainty assessment. Atmos Environ 43:5112-5122. doi: 10.1016/j.atmosenv.2009.04.060 